\title{
Pemasaran Dan Persaingan Sofitel Bali Nusa Dua Beach Resort Sebagai Sebuah Atraksi Wisata
}

Malene Haahr Poulsen a, 1, Gde Indra Bhaskara ${ }^{2}$

${ }^{1}$ malene.poulsen@hotmail.com, ${ }^{2}$ gbhaskara@unud.ac.id

a Program Studi Sarjana Destinasi Pariwisata, Fakultas Pariwisata,Universitas Udayana, Jl. Dr. R. Goris, Denpasar, Bali 80232 Indonesia

\section{Abstract}

This research takes place in Sofitel Bali Nusa Dua Beach Resort. It aims to analyse the marketing and competition of Sofitel Bali as a tourist attraction. This is achieved by using the concept of marketing mix and Porter's Five Forces. The research of a hotel as a tourist attraction is conducted, because a hotel does not only serve as a place to sleep, rather does it serve a bigger role in the destination by giving the tourist an experience based on the product offered. This research uses both qualitative and quantitative data collected through observation and interviews from primary and secondary sources.

The result of the research shows that the marketing of Sofitel Bali Nusa Dua Beach Resort as a tourist attraction is based on the target group, which is family. The brunch includes food, drinks and other facilities, such as a playground, pool, beach and entertainment. The promotion mostly happens through word of mouth and digital marketing. The biggest competitors are St. Regis, Westin and W Seminyak. Some substitute products are high tea, Sunday markets, beach clubs and even other tourist attractions. Suppliers and buyers have great powers, but this has not caused any problems for Sofitel Bali.

Some advice to be given to the management of the brunch at Sofitel Bali is to always motivate the employees, adapt the product to meet the needs of the target group, to promote the pool and beach as a part of the brunch, to maintain a good relationship with suppliers and always be aware of competitors and take advantage of the uniqueness of the brunch at Sofitel Bali by specializing further in culture and life style.

Keywords : hotel, tourist attraction, marketing, Sofitel

\section{PENDAHULUAN}

Sebuah destinasi pariwisata terdiri dari empat bagian, yaitu akses, atraksi, fasilitas dan kelembagaan (Cooper dkk, 1993). Salah satu fasilitas yang memiliki peran besar dalam destinasi pariwisata adalah akomodasi. Akomodasi dapat berupa hotel, resort, home stay dan lain sebagainya. Menurut kamus besar bahasa Indonesia akomodasi adalah "sesuatu yang disediakan untuk memenuhi kebutuhan, misalnya tempat menginap atau tempat tinggal sementara bagi orang yang bepergian" (Kamus Besar Bahasa Indonesia, 2017). Namun, sebuah fasilitas akomodasi dapat menjadi lebih dari hanya sebuah tempat menginap. Sebuah hotel atau resort dapat menyediakan aktivitasaktivitas yang menarik wisatawan untuk mengunjungi hotel atau resort tersebut bukan dengan tujuan untuk menginap, tetapi untuk menikmati aktivitas dan pelayanan yang ditawarkan. Dengan demikian hotel dan resort dapat menjadi sebuah atraksi wisata karena ada daya tarik selain akomodasi yang disediakan.

Di Bali terdapat persaingan yang sangat besar antara semua tempat akomodasi yang ada. Itu dikarenakan adanya overflow akomodasi, di mana banyak tempat mengalami kesulitan untuk menjual kamar yang disediakan. Maka banyak tempat akomodasi perlu mengembangkan produk yang ditawarkan, agar wisatawan lebih tertarik untuk memilih produk tersebut dari pada memilih produk yang lain. Dengan menyediakan berbagai jenis aktivitas maka sebuah hotel atau resort dapat menjadi lebih kompetitif dalam menarik wisatawan untuk menginap di tempat tersebut. Hotel tersebut juga dapat menarik wisatawan untuk mengunjungi tempatnya tanpa menginap. Dengan demikian hotel atau resort tersebut memiliki fungsi sebagai atraksi wisata. Salah satu hotel di Bali yang telah menyediakan aktivitas-aktivitas yang menarik wisatawan untuk berkunjung tanpa menginap adalah Sofitel Bali Nusa Dua Beach Resort. Hotel tersebut membuat brunch di restoran Cut Catch Cucina setiap hari Sabtu dan Minggu dan menyediakan fasilitas yang ada di hotelnya, seperti kolam, tempat main anak-anak dan pantai, sehingga wisatawan dapat menikmati brunch dan kemudian menikmati fasilitas lain yang ada di hotelnya. Dengan demikian wisatawan tersebut menghabiskan banyak waktu di Sofitel Bali Nusa Dua Beach Resort tanpa menginap, maka dapat dikatakan bahwa 
hotel tersebut menjadi sebuah atraksi wisata dikarenakan fasilitas dan aktivitas yang disediakan.

Berdasarkan latar belakang diatas maka rumusan masalah yang tepat untuk penelitian ini adalah :

1. Bagaimana pemasaran Sofitel Bali Nusa Dua Beach Resort sebagai sebuah atraksi wisata?

2. Bagaimana persaingan Sofitel Bali Nusa Dua Beach Resort sebagai sebuah atraksi wisata?

\section{TINJAUAN PUSTAKA}

Dalam penelitian pemasaran dan persaingan Sofitel Bali Nusa Dua Beach Resort sebagai sebuah atraksi wisata digunakan beberapa konsep yang digunakan untuk mengakaji diantaranya :

\section{Marketing Mix (Bauran Pemasaran)}

Menurut Kotler dan Armstrong (2008) marketing mix adalah kombinasi variabelvariabel pemasaran yang dapat dikontrol dan dapat digunakan oleh suatu usaha untuk mencapai penjualan dalam suatu target pasar. Bauran pemasaran tediri dari 7 P, yaitu product, place, price, promotion, people, processes dan physical evidence. Product meliputi penciptaan produk baru dan perkembangan produk. Price adalah harga yang harus kompetitif dan menguntungkan. Promotion meliputi semua cara yang digunakan untuk komunikasi dengan pasar dengan memasarkan apa yang dapat ditawarkan. People adalah pegawai, pengelola dan semua orang yang terlibat. Processes meliputi proses dan metode yang digunakan untuk menawarkan pelayanan. Physical Evidence adalah pengalaman yang didapatkan dari suatu produk atau pelayanan (Lin, 2011)

\section{Porter's Five Forces}

Porter's five forces adalah sebuah analisis yang menggunakan lima kekuatan industri untuk menentukan intensitas persaingan dan profitabilitasnya. Lima kekuatan tersebut adalah industry rivalry, threat of new entrants, threat of substitutes, bargaining power of buyers dan bargaining power of suppliers (Porter, 1979). Industry rivalry adalah persaingan yang terjadi di sebuah industri dan meliputi harga diskon, perkembangan produk baru, kegiatan promosi dan perbaikan pelayanan. Threat of entry adalah perusahaan baru yang ingin mendapatkan bagian dari pasar. Threat of substitutes adalah perusahaan yang menawarkan produk yang memiliki fungsi yang sama atau mirip dan dapat dijadikan sebuah pengganti. Bargaining power of buyers adalah pembeli yang memberi tekanan dengan meminta harga yang lebih rendah atau produk yang lebih berkualitas. Bargaining power of suppliers adalah kekuatan pemasok dalam meningkatkan harga atau membatasi kesediaan untuk menambah nilai bagi mereka sendiri (Porter, 2008).

3. Konsep Hotel

Hotel merupakan sarana tempat tinggal umum untuk wisatawan dengan memberikan pelayanan jasa kamar, penyedia makanan dan minuman serta akomodasi dengan syarat pembayaran (Lawson, 1976).

4. Konsep Atraksi Wisata

Atraksi wisata adalah suatu sumber yang permanen yang diatur dan dikelola demi kenikmatan, hiburan dan pendidikan masyarakat yang berkunjung (Middleton, 1994). Menurut Lew (1987) atraksi wisata adalah semua komponen dalam sebuah destinasi pariwisata yang menarik wisatawan dari daerah asal. Menurut Gartner (1996) atraksi wisata adalah bagian utama dari pengalaman wisatawan. Gartner juga mengatakan bahwa semua komponen dalam sebuah destinasi pariwisata dapat dijadikan sebagai atraksi wisata dengan pemasaran yang tepat.

\section{METODE}

Penelitian ini dilakukan di restoran Cut Catch Cucina yang berada di dalam Sofitel Bali Nusa Dua Beach Resort yang terletak di Lot N5 Nusa Dua Tourism Complex. Metode yang digunakan dalam penelitian ini yaitu kualitatif yang akan terfokus pada pemasaran dan persaingan Sofitel Bali Nusa Dua Beach Resort sebagai sebuah atraksi wisata berdasarkan salah satu produk yang ditawarkan, yaitu brunch. Data kuantitatif yang digunakan adalah harga produk. Dalam penelitian ini digunakan data primer yang didapatkan langsung oleh Peneliti berupa data tentang pemasaran brunch di Sofitel, seperti target pasar, kegiatan promosi, citra, konsep dan produk, serta data tentang persaingan brunch di Sofitel, yaitu data seperti persepsi wisatawan, kondisi pemasok dan kondisi pegawai. Data yang ada dalam penelitian ini didapat melalui observasi, wawancara dengan Digital Marketing Coordinator dan Restaurant Manager di Sofitel 
Bali Nusa Dua Beach Resort serta wisatawan yang membeli produk brunch. Teknik analisis data yang digunakan dalam penelitian ini yaitu dengan mengelompokkan data yang telah terkumpul kemudian menguji reliabilitas dan validitas dengan menggunakan teknik triangulation. Kemudian data mengenai pemasaran dan persaingan Sofitel Bali Nusa Dua Beach Resort sebagai sebuah atraksi wisata di sajikan dalam bentuk pemaparan analisis untuk kemudian ditarik kesimpulan.

\section{HASIL DAN PEMBAHASAN}

Sofitel Bali Nusa Dua Beach Resort adalah sebuah luxury resort berbintang lima yang terletak di kawasan pariwisata Nusa Dua Indonesia Tourism Development Complex. Sofitel Bali Nusa Dua Beach Resort memiliki 415 kamar, 22 suite dan 17 villa. Sofitel Bali juga memiliki dua restoran, yaitu Kwee Zeen dan Cut Catch Cucina, serta tiga bar, yaitu L'oh Pool Bar, Beach Bar dan Le Bar Lobby Bar. Fasilitas yang lain yang ada di Sofitel Bali adalah kolam, kolam khusus untuk anak-anak, tempat main untuk anak-anak, kids club, spa, fitness centre, kapel pernikahan, dua ballroom dan delapan ruangan untuk rapat bisnis (Sofitel, 2017).

\subsection{Pemasaran Sofitel Bali Nusa Dua Beach Resort sebagai sebuah Atraksi Wisata}

Pemasaran Sofitel Bali Nusa Dua Beach Resort sebagai sebuah atraksi wisata berdasarkan produk brunch dapat dianalisis dengan bauran pemasaran yang terdiri dari tujuh $\mathrm{P}$, yaitu product, place, price, promotion, people, processes dan physical evidence.

\section{a. Product (Produk)}

Produk yang ditawarkan oleh Sofitel Bali sebagai sebuah atraksi wisata adalah brunch yang diadakan setiap hari Sabtu dan Minggu di restoran yang bernama Cut Catch Cucina. Brunch merupakan buffet dan produknya terdiri dari tiga macam paket, yaitu yang pertama semua jenis makanan dan minuman tidak beralkohol. Paket ke-dua termasuk semua jenis makanan, minuman tanpa alkohol, cocktail dan sparkling wine. Paket ke-tiga juga termasuk sampanye.

Produk brunch tidak hanya meliputi makanan dan minuman yang didapatkan. Wisatawan yang membeli produk brunch di Sofitel Bali juga boleh menggunakan fasilitas lain yang ada di hotel tersebut, yaitu tempat main anak-anak, kolam dan pantai. Seperti kolam lagoon dan kolam anak-anak. Brunch diadakan jam 11.00 sampai jam 15.00 . Wisatawan yang membeli produk brunch dipersilahkan untuk menggunakan fasilitas yang lain pada jam itu, akan tetapi mereka juga dipersilahkan untuk menggunakan fasilitas tersebut setelah brunch. Berdasarkan wawancara dengan wisatawan yang membeli paket brunch, maka dapat diketahui bahwa delapan dari sepuluh orang yang diwawancarai menggunakan fasilitas seperti kolam, pantai dan tempat main anak-anak. Dua wisatawan yang tidak menggunakan fasilitas tersebut mengatakan bahwa mereka tidak tahu itu termasuk dalam produk.

Produk brunch dikembangkan secara terusmenerus. Saat ini brunch yang diadakan bertema chic brunch. Arti dari chic adalah anggun atau cantik. Tema atau konsep ini dapat dilihat dari produk yang ditawarkan. Pada saat brunch ada seorang perancang busana yang menampilkan bajunya dan sekalian menjualnya di depan pintu masuk Cut Catch Cucina. Adapun fashion show dengan baju tersebut. Selain fashion show ada juga musik dari sebuah band dan pertunjukan sulap dari seorang pesulap. Pembeli tidak hanya mendapatkan makanan dan minuman, akan tetapi ia mendapatkan satu hal yang lebih, yaitu hiburan.

Konsep brunch sering dikembangkan, sehingga wisatawan yang sering mengunjungi brunch tidak merasa bosan dengan konsep yang sama. Produk juga disesuaikan dengan musim. Pada hari raya Natal, Paskah, Halloween, Hari Ibu dan hari spesial yang lain ada penyesuaian terhadap makanan, minuman dan perhiasan.

Sofitel Bali menggabungkan budaya Perancis dan Bali. Ini dapat dilihat dari produk brunch, karena makanan yang ditawarkan merupakan gabungan antara makanan Perancis dan Bali. Dari Perancis ada makanan seperti keju, roti dan wine. Dari Bali ada makanan seperti ayam betutu dan babi guling. Gabungan antara dua budaya seperti ini memberikan nilai tambahan terhadap produk, karena pembeli mendapatkan yang terbaik dari dua budaya.

\section{b. Place (Saluran Distribusi)}

Sofitel Bali menjual produk brunch langsung sama pembeli. Wisatawan yang ingin membeli produk tersebut dapat datang langsung ke Sofitel Bali untuk membelinya. Untuk menghindari adanya kehabisan produk, karena kapasitas restoran Cut Catch Cucina 
terbatas, maka pembeli dapat melakukan pemesanan atau booking melalui telpon atau dengan datang langsung ke hotel atau restoran tersebut. Sofitel Bali tidak menggunakan perantara atau pihak ke-tiga untuk menjual produk brunch.

Sofitel Bali juga dapat menjangkau pasar melalui pihak lain, di mana produk brunch merupakan sebuah hadiah. Yang dimaksud dengan itu adalah bahwa perusahaan lain membuat sebuah kompetisi atau kuis di sosial media mereka sendiri. Sosial media yang digunakan sering merupakan Instagram dan Facebook. Contoh kompetisi yang dimaksud adalah bahwa semua partisipan diminta untuk posting ulang atau repost satu postingan. Setelah itu perusahaan yang adakan kompetisi akan memilih satu pemenang. Pemenang tersebut kemudian akan mendapatkan sebuah hadiah atau prize yang merupakan produk brunch. Itu merupakan promosi yang murah bagi Sofitel Bali karena tidak membutuhkan tenaga kerja banyak dari Sofitel Bali.

\section{b. Price (Harga)}

Harga brunch ada tiga, karena ada tiga paket brunch yang berbeda. Harga paket tanpa alkohol adalah IDR 499.000++. Harga paket termasuk cocktail dan sparkling wine adalah IDR 699.000++ dan harga paket yang termasuk sampanye adalah IDR 1.399.000++. "++" berarti harga belum ditambahkan 10\% service charge atau biaya pelayanan dan $11 \%$ government charge atau pajak. Anak-anak di bawah umur 12 tahun tidak dikenakan biaya. Harga brunch ditentukan berdasarkan perhitungan rata-rata konsumsi setiap pembeli brunch.

Tahun 2017 harga telah naik dengan IDR 100.000. Tahun 2016 harga brunch yang paling murah adalah IDR 399.000++. Kenaikan harga terjadi berdasarkan perhitungan rata-rata konsumsi pembeli. Dengan adanya kenaikan harga dari pemasok dan pengeluaran lain yang juga meningkat, karena ada kenaikan gaji, maka harga brunch juga perlu naik, agar dapat menutupi semua pengeluaran.

Untuk meningkatkan penjualan maka Sofitel Bali memberikan diskon kepada beberapa pembeli brunch. Pembeli yang dapat menikmati diskon adalah orang yang berkewarganegaraan Perancis tetapi tinggal tetap di Bali atau yang disebut expat Perancis. Mereka dapat menikmati diskon sebesar 20\%. Pemegang kartu kredit BCA juga dapat menikmati diskon sebesar 25\%. Pada saat ada acara tertentu, maka wisatawan tertentu juga dapat menikmati diskon. Contohnya adalah pada saat Hari Ibu, maka para ibu yang membeli produk brunch dapat menikmati diskon sebesar $20 \%$.

Apabila harga brunch di Sofitel Bali dibandingkan dengan brunch lain yang disediakan di Bali, maka dapat diketahui bahwa harga Sofitel Bali itu tidak mahal. Harga brunch yang paling murah di Mulia Bali adalah IDR 599.000++. Harga anak-anak yang berumur 3-8 tahun adalah IDR 339.000++. Harga brunch yang paling murah di St. Regis Bali adalah IDR 690.000. Anak-anak yang berumur 4-12 tahun dikenakan biaya sebesar IDR 345.000 . (Starwood Preferred Guest, 2017).

\section{c. Promotion (Promosi)}

Sofitel Bali lebih mempromosikan produk brunch melalui word of mouth di mana pembeli brunch menceritakan produk dan pengalaman ke temannya, sehingga teman tersebut juga ingin membeli produknya. Promosi tersebut sangat efektif dibandingkan dengan promosi melalui iklan, karena orang cenderung lebih mempercayai apa yang diceritakan sama temannya, dari pada apa yang dilihat di iklan.

Jenis promosi yang lain adalah advertising atau pengiklanan. Itu dilakukan dengan membuat sebuah iklan yang disiarkan di salah Hard Rock Radio Bali. Selain itu Sofitel Bali telah memasang sebuah billboard di dekat Pantai Nusa Dua dan di dekat Bandara Ngurah Rai untuk mengiklankan brunch yang ditawarkan. Adapun flyer yang disebarkan di tempat atau acara tertentu, seperti pada saat Jazz Festival yang diadakan di Taman Baghawan. Sofitel Bali juga mempromosikan brunch di majalah-majalah.

Sofitel Bali juga menjaga hubungan dengan wisatawan yang pernah membeli produk brunch dan melakukan promosi dengan menghubungi kembali wisatawan tersebut. Jenis promosi tersebut adalah sales promotion yang bertujuan untuk meningkatan penjualan. Sofitel Bali menghubungi wisatawan melalui telepon pada hari Jumat atau Sabtu untuk mempromosi produk brunch dan memberikan diskon sebesar $20 \%$ apabila wisatawan tersebut melakukan pemesanan langsung melalui telepon untuk brunch minggu itu. Jenis sales promotion lain adalah dengan kerjasama 
dengan bank BCA, di mana pemegang kartu kredit BCA dapat diskon sebesar $25 \%$.

Sofitel Bali juga melakukan promosi melalui digital marketing, yaitu melalui media sosial dan situs web Sofitel sendiri. Media sosial yang digunakan adalah Facebook, Twitter dan Instagram. Tripadvisor juga merupakan sarana promosi bagi Sofitel Bali.

\section{d. People (Partisipan)}

Ada banyak orang yang terlibat dalam penyediaan produk brunch di Sofitel Bali. Bagi wisatawan yang melakukan pemesanan melalui concierge ada seorang ibu atau bapak yang menghubungkan wisatawan tersebut dengan Cut Catch Cucina. Bagi orang yang melakukan pemesanan melalui telepon maka mereka disambungkan dengan resepsi atau front office. Pada saat datang ke brunch maka wisatawan akan berjumpa dengan seorang penerima tamu atau host. Penerima tamu tersebut adalah seorang perempuan yang memiliki penampilan cantik dan anggun dengan gaun hitam panjang. Setelah itu wisatawan akan berjumpa dengan pelayan, yaitu waiter, waitress dan bartender. Pelayan bertugas untuk membuat produk brunch sebaik mungkin dengan menjelaskan tentang produknya, menyediakan makanan yang a la carte, menawarkan dan memberikan minuman, melipatkan napkin, merapikan meja dan lain sebagainya.

Adapun pengelola di brunch, namun tidak semua wisatawan dapat berjumpa dengan pengelola. Akan tetapi, pengelola tetap memiliki peran penting dalam penyediaan brunch, karena pengelola yang memastikan bahwa semua berjalan dengan lancar dan siap membantu apabila terjadi masalah. Selain itu ada juga orang lain terlibat dalam proses penyediaan dan penjualan produk brunch, yaitu dari bagian pemasaran. Wisatawan dapat berjumpa dengan orang pemasaran sebelum membeli produk, karena diberikan flyer, atau karena berjumpa dengan orang tersebut di sebuah pameran. Wisatawan juga dapat berjumpa dengan orang pemasaran setelah membeli produk brunch, yaitu untuk menciptakan hubungan baik dan untuk membuat wisatawan tersebut datang kembali.

Rata-rata kunjungan brunch adalah 100 sampai 150 orang. $30 \%$ dari jumlah tersebut merupakan repeater. Oleh karena itu, orang yang bekerja dengan penyediaan dan penjualan produk brunch perlu membuat repeater tersebut merasa diterima pada saat datang kembali. Repeater diberikan pelayanan tambahan, di mana pegawai dapat menyebut nama wisatawan tersebut, sehingga ia merasa lebih dihargai dan sekaligus lebih akrab. $80 \%$ dari jumlah kunjungan merupakan orang asing atau yang tidak berkewarganegaraan Indonesia. Oleh karena itu, bahasa Inggris adalah suatu kewajiban dari semua pegawai.

Dalam proses penerimaan pegawai baru, maka ada tiga kualifikasi yang perlu dipenuhi. Yang pertama adalah bahasa Inggris, kemudian pengalaman sebelumnya dan juga kepribadian. Dengan adanya tiga kualifikasi tersebut hanya pegawai yang benar-benar pantas yang dapat diterima. Selain itu ada juga standar dari LQA dan Accor. LQA adalah Leading Quality Assurance, yaitu sebuah divisi inspeksi yang berlaku di seluruh dunia untuk memeriksa kualitas pelayanan di sebuah hotel dan memberikan pelatihan apabila diperlukan. Accor adalah kelompok hotel, di mana Sofitel Bali adalah anggota. Dalam penerimaan pegawai baru standar dari LQA dan Accor juga perlu dipertimbangkan dan dijadikan patokan.

Bagi pegawai yang baru mulai bekerja di Cut Catch Cucina ada pelatihan selama 90 hari yang dibuat oleh bagian HRD (Human Ressource Department). Adapun rotasi setiap bulan, di mana pegawai dapat mencoba dan mengetahui divisi yang lain, sehingga dapat mengetahui semua bagian dari Sofitel Bali.

Motivasi merupakan hal yang penting, karena motivasi yang memberikan pegawai semangat untuk bekerja lebih keras dan memberikan pelayanan yang terbaik. $\mathrm{P}$ adalah bahwa mereka cepat kehilangan motivasi. Itu terjadi dikarenakan umur yang muda, di mana kepribadian masih dalam proses pembangunan. Untuk mengatasi masalah tersebut pengelola memberikan motivasi dengan memberikan penghargaan kepada siapapun yang mencapai prestasi dalam karir dalam waktu yang pendek.

\section{d. Processes (Proses)}

Proses merupakan hal yang penting dalam penyediaan dan penjualan sebuah produk. Proses mulai dari pengelolaan, di mana semua keputusan diambil dan perencanaan dilakukan. Pengelolaan termasuk pengelolaan dalam bidang pemasaran. Pengelolaan di Cut Catch Cucina termasuk pengelolaan di dalam restoran dan di dapur. Di dalam restoran terjadi pelayanan terhadap wisatawan, dan di dapur 
terjadi penyiapan makanan yang menjadi inti dari produk brunch. Namun, semua pengelolaan di Sofitel Bali terlibat dalam proses penyediaan produk brunch. HRD terlibat dalam penerimaan pegawai baru. Maintenance atau departmen perawatan terlibat dalam perbaikan restoran, interior dan lain sebagainya. Front office terlibat karena mereka yang menerima wisatawan pada saat baru datang ke Sofitel Bali. Departmen pembelian terlibat karena membeli kebutuhan brunch.

Selain pengelolaan semua pegawai juga terlibat dalam proses penyediaan dan penjualan produk brunch. Baik resepsionis yang menerima wisatawan pada saat baru datang ke Sofitel, pegawai housekeeping yang membersihkan kamar mandi dan menyapa wisatawan pada saat mereka ke kamar mandi, maupun pemasak dan waiter. Proses brunch dilihat dari segi makanan dan minuman dimulai dari pembelanjaan bahan masak dan penyiapan makanan. Karena makanan meliputi masakan Indonesia, terutama Bali, dan Western, terutama Perancis, maka penyiapan makanan membutuhkan bahan masak yang khusus dan untuk memasak bahan tersebut juga membutuhkan keterampilan yang khusus.

Proses brunch dilihat dari sudut pandang wisatawan bermulai dari pemasaran atau pemesanan. Setelah melakukan pemesanan, maka wisatawan datang ke Sofitel Bali. Di sini ia akan diantar dari lobby ke restoran Cut Catch Cucina oleh seorang resepsionis. Di depan Cut Catch Cucina wisatawan tersebut akan diterima oleh seorang host yang memberikan welcome drink dan sebuah face towel yang dingin. Setelah itu wisatawan akan diantar ke meja yang telah disiapkan, karena kebanyakan wisatawan melakukan pemesanan terlebih dahulu. Di meja wisatawan akan dilayani oleh waiter dan waitress dan juga oleh bartender pada saat melakukan pemesanan minuman. Setelah selesai brunch wisatawan dapat menggunakan fasilitas kolam atau pantai, di mana mereka akan dilayani oleh pegawai yang bekerja di tempat tersebut.

Proses penyediaan produk brunch adalah proses yang panjang dan rumit dan meliputi banyak orang. Agar proses tersebut berjalan dengan lancar, maka perlu pengelolaan yang kuat dan ketat. Semua orang yang terlibat dalam proses perlu mengetahui peran dan tugas masing-masing.

\section{e. Physical Evidence (Bukti Fisik)}

Sofitel Bali merupakan hotel berbintang lima. Bintang lima diberikan berdasarkan beberapa hal, termasuk kualitas pelayanan, bangunan, interior, dan desain. Hal ini juga merupakan bukti fisik yang didapatkan oleh wisatawan yang membeli produk brunch. Pelayanan yang diberikan adalah pelayanan yang bagus, di mana wisatawan merasa diterima dan dihargai. Ini merupakan hal yang sangat penting dalam penyediaan dan penjualan produk yang intangible. Contoh pelayanan yang bagus yang diberikan pada saat brunch adalah bahwa wisatawan tidak perlu meminta minuman air putih, karena gelas selalu diisi oleh pegawai, agar tidak pernah kosong.

Bangunan, interior dan desain adalah hal lain yang juga merupakan bukti fisik. Desain didominasi oleh batu granit putih, kayu warna coklat dan banyak tanaman hijau. Ini memberikan penampilan yang luxurious. Untuk Cut Catch Cucina sendiri desain lebih didominasi oleh warna yang lebih gelap, seperti hitam, merah tua dan oranye tua. Akan tetapi kayu warna coklat masih digunakan juga. Warna yang lebih gelap memberikan penampilan yang exclusive. Terkait dengan bangunan dan interior ada juga sebuah tempat foto di depan pintu masuk Cut Catch Cucina, di mana wisatawan dapat berfoto bersama temannya untuk mengabdikan momen brunch di Sofitel Bali. Tempat foto terdiri dari foto bertema Perancis dengan tulisan tentang brunch.

Seragam yang digunakan oleh pegawai di Sofitel Bali juga merupakan bukti fisik karena mempengaruhi pengalaman yang didapatkan oleh wisatawan. Seragam lebih terinspirasi dari budaya Perancis dari pada budaya Bali. Seragam tergantung pada jabatan. Akan tetapi, ada dua seragam yang paling menonjol, yaitu seragam penerima tamu yang merupakan gaun hitam, dan seragam waiter dan waitress yang merupakan kaos putih, celemek warna biru tua, syal warna merah dan topi warna biru tua. Warna tersebut terinspirasi dari bendera Perancis.

Bukti fisik lainnya adalah produk tambahan yang didapatkan. Produk ini telah dijelaskan, yaitu bahwa wisatawan selain 
mendapatkan makanan dan minuman juga mendapatkan hiburan dengan adanya fashion show, musik dari band dan seorang pesulap. Produk brunch juga meliputi fasilitas kolam, pantai dan tempat main anak-anak. Ini juga merupakan bukti fisik dari produk brunch. Di pantai ada sunbed yang boleh digunakan. Kolamnya terdiri dari satu lagoon pool yang besar, beberapa kolam kecil yang terletak dekat kamar, dan satu kolam untuk anak-anak yang memiliki seluncuran air dan air mancur. Di sebelah kolam ada juga sunbed yang boleh digunakan, dan wisatawan yang ingin berenang juga dipinjamkan handuk.

\subsection{Persaingan Sofitel Bali Nusa Dua Beach Resort sebagai sebuah Atraksi Wisata}

Persaingan Sofitel Bali Nusa Dua Beach Resort sebagai atraksi wisata dengan produk brunch dapat dianalisis dengan Porter's Five Forces. Lima kekuatan ini dapat menentukan kondisi persaingan yang ada saat ini dan ancaman yang mungkin akan muncul di masa yang akan datang. Yang termasuk dalam persaingan menurut Porter's Five Forces adalah pesaing yang menawarkan produk yang sama, pesaing yang menawarkan produk yang dapat menjadi pengganti produk brunch, pesaing yang mungkin akan muncul di masa yang akan datang, kekuatan pembeli dan kekuatan pemasok dan pegawai.

\section{a. Industry Rivalry}

Persaingan Sofitel Bali sebagai sebuah atraksi yang bersifat langsung adalah hotel atau restoran yang menyediakan produk yang sama, yaitu brunch. Pesaing terbesar Sofitel Bali sebagai atraksi wisata berdasarkan produk brunch adalah St. Regis. Akan tetapi, seperti yang telah dikatakan, harga produk brunch di St. Regis Nusa Dua lebih mahal dari pada harga di Sofitel Bali. Ini merupakan hal yang penting dalam persaingan. Berdasarkan konsep maka brunch di Sofitel Bali dan di St. Regis hampir sama, maka harga menjadi asas untuk bersaing dengan pesaing tersebut.

Pesaing yang lain adalah restoran Starfish Bloo yang terletak di W Retreat di Seminyak. Starfish Bloo juga menyediakan brunch pada hari Minggu. Starfish Bloo merupakan pesaing besar berdasarkan lokasi. Dikarenakan lokasi di Seminyak, ini menjadi lebih menarik bagi wisatawan yang menginap di daerah Seminyak dan sekitarnya. Berdasarkan harga maka produk brunch di Sofitel Bali lebih murah, karena harga produk brunch yang paling murah di Starfish Bloo adalah IDR. 535.000++ (Marriot, 2017).

Westin Resort Nusa Dua juga merupakan pesaing besar. Westin menyediakan brunch pada hari Minggu dengan konsep keluarga. Target pasar Sofitel Bali adalah keluarga, akan tetapi konsep Sofitel Bali masih berbeda dengan konsep Westin meskipun target pasar samasama keluarga. Konsep Sofitel Bali adalah Chic brunch, sedangkan konsep Westin lebih berfokus pada anak-anak. Berdasarkan harga maka dapat diketahui bahwa brunch di Westin lebih murah dari pada Sofitel Bali karena harga produk brunch yang paling murah adalah IDR. 360.000++ (Marriot, 2017).

Dalam persaingan, lokasi menjadi sebuah keunggulan, karena Nusa Dua merupakan tempat yang unik, asri dan jauh dari keramaian seperti di Seminyak. Threat of New Entrants

Perusahaan yang baru masuk ke industri pariwisata di Bali dapat memberi tekanan pada Sofitel Bali, dikarenakan perusahaan baru dapat merupakan pesaing baru.

Menurut penelitian jurnal yang dibuat oleh Park dkk. (2014) yang berjudul "Assessing Country Attractiveness of Indonesia and Recommended Entry Mode: Hospitality Industry" perusahaan hotel yang baru buka di Indonesia merupakan ancaman yang cukup besar. Itu dikarenakan pembukaan hotel baru membutuhkan modal yang besar dan juga membutuhkan perizinan dari pemerintah. Akan tetapi, karena tidak ada proses pembuatan produk, karena produk itu merupakan pelayanan, maka pembukaan hotel baru adalah kegiatan yang cukup mudah bagi orang yang mempunyai modal dan ada relasi pemerintah yang dapat memudahkan proses perizinan.

Menurut artikel di Kompas.com (Hilda B Alexander, 2016) ada 14 hotel mewah yang mau dibuka di Bali mulai dari saat menulis artikel hingga 2019 mendatang. 14 hotel baru itu akan mencakup 2.040 kamar. 14 hotel tersebut adalah Waldorf Astoria Uluwatu, Waldorf Astoria Ubud, Solis Capella, Cordis Nusa Dua, Langham Place, Raffles, Fairmont, Mandarin Oriental, Kempinski Nusa Dua, Rosewood Tanah Lot, Shangri-La Nusa Dua, Jumeirah, Andaz dan Edition. Pembukaan 14 hotel ini membuktikan kemudahan membuka hotel atau restoran baru di Bali. 14 hotel ini juga dapat menjadi pesaing Sofitel Bali sebagai 
atraksi, karena 14 hotel ini adalah hotel mewah, maka ada kemungkingan besar akan menyediakan produk atau pelayanan yang dapat dibeli oleh wisatawan yang tidak menginap di hotel tersebut, seperti produk brunch.

\section{b. Threat of Substitutes}

Produk yang merupakan pesaing besar dan dapat menjadi pengganti produk brunch ada banyak. Contoh produk yang paling mirip dengan produk brunch adalah high tea atau afternoon tea yang disediakan di banyak restoran dan hotel di Bali. Beberapa hotel dan restoran di Bali yang menyediakan produk ini adalah Metis Seminyak, W Seminyak, Ayana Jimbaran, St. Regis Nusa Dua dan Sheraton Kuta (Kim Wilson, 2017). Produk ini terdiri dari teh, kue dan roti yang biasanya dibeli pada sore hari. High tea atau afternoon tea merupakan produk dengan konsep yang sama dengan brunch di Sofitel Bali karena luxurious dan chic. Akan tetapi, produk ini biasanya hanya terdiri dari makanan dan minuman, dan pembeli tidak mendapatkan pelayanan lebih dari itu.

Produk lain yang dapat menjadi pengganti brunch adalah produk yang dapat dibeli di beach club atau pool club. Tempat ini merupakan restoran yang terletak di pinggir pantai dan memiliki pantai sendiri dan sering juga memiliki kolam. Wisatawan yang belanja makanan dan minuman dapat menggunakan fasilitas kolam dan pantai. Produk ini dapat menggantikan produk brunch karena wisatawan sama-sama mendapatkan makanan, minuman dan dapat menggunakan fasilitas kolam dan pantai. Beberapa beach club dan pool club yang berada di Bali adalah Finn's Beach Club Canggu, Komune Beach Club Gianyar, Surt and Turf Nusa Dua, Cocoon Seminyak, Nikki Beach Bali dan Potato Head Seminyak (BALI, 2017).

Selain high tea dan beach club produk lain yang dapat menjadi pengganti brunch adalah Sunday market atau pasar hari Minggu. Sunday market adalah pasar yang hanya buka pada hari Minggu dan biasanya dibuka di dalam sebuah restoran. Barang yang dijual dapat merupakan baju, perhiasan, mainan, buku, dan juga makanan dan minuman. Beberapa Sunday market yang ada di Bali adalah Old Man's Market Canggu, Samadi Sunday Market Canggu dan Mercure Resort Sanur (Melinda, 2016)
Dengan melihat Sofitel Bali sebagai sebuah atraksi wisata, maka atraksi wisata lain di Bali juga dapat menjadi pengganti brunch. Atraksi wisata seperti Tanah Lot, Uluwatu, Bali Bird Park, Bali Safari Park dan lain sebagainya juga dapat menjadi pengganti brunch meskipun produknya tidak terlalu mirip atau sama. Dari semua pesaing yang dapat menjadi pengganti produk brunch, maka high tea dan beach club merupakan persaing terbesar karena memiliki produk yang paling mirip dengan brunch di Sofitel, maka dapat memenuhi kebutuhan yang sama bagi wisatawan yang berkunjung.

\section{c. Bargaining Power of Buyers}

Dengan adanya kenaikan harga tahun 2017 jumlah kunjungan juga tetap meningkat. Itu menunjukkan bahwa pembeli tidak mendorong Sofitel Bali untuk menjual produk dengan harga yang labih murah. Pembeli rela untuk membayar harga yang ditetapkan oleh Sofitel Bali. Ini dapat diperkuatkan dengan hasil dari wawancara dengan wisatawan yang membeli produk brunch di Sofitel Bali. Delapan dari sepuluh wisatawan yang diwawancarai mengatakan bahwa harga brunch masih pantas dan sesuai dengan produk yang didapatkan. Dua orang dari sepuluh wisatawan mengatakan bahwa harganya sedikit mahal. Ini menunjukkan bahwa mereka mungkin tidak mau beli produknya apabila harganya naik lagi.

Hal lain yang perlu diperhatikan adalah bahwa biaya untuk mengganti produk brunch dengan produk yang lain tidak ada, maka ini sangat mungkin dilakukan oleh wisatawan. Hal tersebut menjadi kekuatan bagi wisatawan. Wisatawan dapat memilih produk dari pesaing dengan mudah dan tanpa biaya tambahan (tidak ada switching cost). Pembeli sebenarnya memiliki kekuatan yang besar, akan tetapi karena pembeli saat ini cenderung merasa puas dengan harga dan produk, maka kekuatan tersebut tidak digunakan untuk menekankan harga.

\section{d. Bargaining Power of Suppliers}

Supplier menurut Porter's Five Forces ada dua, yaitu pemasok dan pegawai. Pegawai merupakan supplier karena memasok tenaga kerja. Pegawai di Cut Catch Cucina cenderung berasal dari Bali, dan hanya 10\% berasal dari luar Bali, yaitu Jakarta, Bandung dan Banyuwangi. Orang yang berkewarganegaraan asing tidak ada yang kerja di Cut Catch Cucina, akan tetapi ada orang asing yang berasal dari 
Perancis yang training di sana selama enam bulan.

Sering terjadi penggantian pegawai atau turnover, karena pegawai yang masih berumur muda mulai bekerja di Sofitel Bali dengan harapan akan cepat berkembang dan mendapatkan jabatan yang tinggi. Akan tetapi, ketika hal tersebut tidak terjadi, maka pegawai akan cepat pindah ke tempat lain. Sering terjadi kesusahan mendapatkan pegawai. Itu dikarenakan standar dan kualifikasi yang cukup tinggi, sehingga orang yang memenuhi persyaratan untuk menjadi pegawai itu tidak banyak.

Dikarenakan jumlah orang yang memenuhi persyaratan itu kecil, maka mereka memiliki kekuatan untuk memilih tempat kerja yang lain. Hanya sedikit orang yang memenuhi persyaratan untuk bekerja di Sofitel Bali, sedangkan ada banyak tempat kerja lain selain Sofitel, maka dapat disimpulkan bahwa pegawai memiliki kekuatan yang besar, dan ini dapat digunakan oleh mereka untuk meminta gaji lebih besar, jabatan lebih tinggi atau kondisi pekerjaan yang lebih bagus.

Kekuatan pemasok juga cukup besar. Sofitel Bali dan terutama Cut Catch Cucina membutuhkan barang yang tidak mudah dicari di Bali. Interior dan desain dengan ciri-ciri Perancis perlu diimpor atau dipesan. Maka jumlah pemasok yang dapat memasok barang tersebut tidak banyak. Untuk pemasok setiap hari ada bahan masakan yang dibutuhkan untuk membuat produk brunch. Bahan tersebut kebanyakan impor, karena Indonesia tidak dapat memproduksikan semua jenis makanan yang disediakan di produk brunch, seperti misalkan keju, oyster atau steak sapi. Akan tetapi, ada juga masakan Indonesia yang disediakan di brunch, di mana Cut Catch Cucina membeli bahan masakan dari pemasok lokal. Untuk mendapatkan bahan masakan, maka Sofitel Bali bekerja sama dengan beberapa pemasok terbesar di Bali.

Jumlah pemasok terbatas, karena Sofitel Bali menggunakan bahan masakan yang berkualitas. Selain itu pemasok cenderung dari luar negeri. Maka dapat disimpulkan bahwa kekuatan pemasok cukup besar, dikarenakan adanya jumlah pemasok yang terbatas. Pemasok memiliki kekuatan untuk meminta harga yang lebih tinggi, karena Sofitel Bali tidak memiliki banyak pilihan untuk memilih pemasok yang lain.

\section{SIMPULAN DAN SARAN 5.1 Simpulan}

Sebagai kesimpulan dapat dikatakan bahwa Sofitel Bali menjadi sebuah atraksi wisata dengan produk brunch. Target pasar adalah keluarga, maka pemasaran perlu diesuaikan terhadap pasar tersebut. Produk yang disediakan adalah brunch yang meliputi makanan dan minuman, serta fasilitas lain seperti tempat main anak-anak, kolam dan pantai. Produk juga meliputi hiburan, yaitu fashion show, band dan pesulap. Sofitel Bali lebih sering menjual produknya langsung, tanpa perantara. Harga adalah antara IDR 499.000++ sampai IDR. 1.399.000++. Promosi lebih sering terjadi melalui word of mouth atau digital marketing, yaitu situs web dan media sosial. Banyak orang terlibat dalam penyediaan dan penjualan produk brunch, baik dari waitress, host, pemasak dan lain sebagainya. Adapun proses yang rumit untuk menyediakan produk brunch yang membutuhkan pengelolaan yang ketat untuk berjalan dengan lancar. Bukti fisik dari brunch adalah interior, fasilitas kolam, pantai dan tempat main anak-anak, pelayanan, hiburan dan lain sebagainya.

Pesaing terbesar Sofitel Bali sebagai atraksi wisata dengan produk brunch adalah St. Regis, Westin dan W Seminyak. Adapun ancaman dari perusahaan baru yang mau buka. Maka Sofitel Bali mengembangkan konsep brunch untuk mengoptimalkan daya saing. Terdapat juga beberapa produk yang dapat menjadi pengganti brunch di Sofitel Bali, seperti high tea, Sunday market, beach club ataupun atraksi wisata lain yang ada di Bali. Pembeli produk brunch memiliki kekuatan untuk menekankan harga, akan tetapi kekuatan ini tidak dipergunakan saat ini. Pemasok juga memiliki kekuatan untuk meminta harga yang mahal, karena tidak terdapat banyak pemasok yang dapat menyediakan bahan dan barang yang dibutuhkan oleh Sofitel Bali. Akan tetapi, kekuatan tersebut masih tidak menyimbulkan masalah.

\subsection{Saran}

Berdasarkan pembahasan di atas maka dapat diberi saran ke pada pengelola produk brunch di Sofitel Bali: 
Tidak melupakan budaya Bali dalam perencanaan produk. Budaya Bali telah tercermin dalam makanan yang disediakan, dan hal tersebut tidak boleh dihilangkan. Akan tetapi, dalam desain interior dan seragam pegawai budaya Bali belum terlalu kuat.

Selalu memotivasikan pegawai, karena pegawai memiliki kekuatan sebagai supplier tenaga kerja, dan Sofitel Bali saat ini telah mengalami kesulitan untuk mendapatkan pegawai yang memenuhi semua kualifikasi, maka perlu menahankan pegawai yang memang telah memenuhi kualifikasi tersebut.

Menyesuaikan produk terhadap taget pasar, yaitu keluarga. Fasilitas kolam untuk anak kecil sudah sangat bagus. Akan tetapi, tempat main anak-anak yang berada di dalam ruangan tidak mempunyai banyak jenis mainan, maka tidak banyak anak kecil menggunakan tempat main tersebut. Selain itu dapat disiapkan satu tempat atau meja khusus untuk makanan untuk anak-anak, yang meliputi makanan yang sering disukai anak kecil.

Memasarkan fasilitas kolam dan pantai yang termasuk dalam produk brunch, karena ini merupakan keunggulan Sofitel Bali dibandingkan dengan pesaing, maka dapat dipasarkan untuk meningkatkan penjualan.

Tetap menjaga hubungan yang baik dengan pemasok, karena pemasok memiliki kekuatan karena tidak ada banyak pemasok yang dapat menyediakan bahan yang dibutuhkan oleh Sofitel Bali.

Memperhatikan pesaing dan memanfaatkan keunggulan dan keunikan yang dimiliki oleh Sofitel Bali dalam persaingan, serta lebih berspesialisasi dalam budaya dan gaya hidup untuk meningkatkan kelayakan sebagai atraksi wisata.

\section{DAFTAR PUSTAKA}

Bali, 2017. 21 Best Beach Clubs in Bali terdapat pada http://www.bali-

indonesia.com/magazine/top10-best-beachclubs-bali.htm. Diakses pada tanggal 1 April 2017.

Cooper et. al. 1993. Tourism Principles \& Practice. England: Longman Group Limited.

Gartner, W.C. 1996. Tourism Development - Principles, Processes, and Policies. New York: Van Nostrand Reinhold.
Hilda B Alexander, 2016. 14 Hotel Mewah Baru Hadir di Bali terdapat pada http://properti.kompas.com/read/2016/04/11/ 094306821/14.Hotel.Mewah.Baru.Hadir.di.Bali.D iakses pada tanggal 1 April 2017.

Kamus Besar Bahasa Indonesia 2017, Akomodasi terdapat pada http://kbbi.web.id/akomodasi. Diakses pada tanggal 2 Maret 2017.

Kim Wilson, 2017. 12 Afternoon High Tea Places in Bali You can Indulge in on your Couple Getaway or Girls Trip terdapat pada https://indonesia.tripcanvas.co/bali/afternoonhigh-tea/. Diakses pada tanggal 1 April 2017.

Kotler dan Armstrong. 2008. Principles of Marketing. New Jersey: Pearson Prentince Hall.

Lawson, Fred. 1976. Hotel Motels and Condominiums (Design Planning and Maintenance). London: First Publish Great Britain by The Architectural Press LTD.

Lew, A.A. 1987. A Framework of Tourist Attraction Research: Toards more Effective Management. Tourism Management, Hal. 155-166.

Lin, Su-Mei. 2011. Marketing Mix (7P) and Performance Assessment of Western Fast Food Industry in Taiwan: An Application by Associating DEMATEL and ANP. China: African Journal of Business Management Vol. 5 (26) Hal. 10634-10644.

Marriot 2017, The Westin Resort Nusa Dua Bali terdapat pada http://www.westinnusaduabali.com/pregobrunch. Diakses pada tanggal 31 Maret 2017.

Marriot 2017, W Retreat Bali terdapat pada https://www.marriott.com/hotels/travel/dpswh -w-bali-seminyak/. Diakses tanggal 10 Maret 2017.

Melinda, 2016. Bali's best Sunday markets \& bazaars Terdapat pada https://www.villabali.com/guide/balis-best-sunday-marketsbazaars/. Diakses pada tanggal 1 April 2017

Middleton, V. T. C. 1994. Marketing in Travel and Tourism. Oxford: Butterworth Heinemann.

Park, dkk. 2014. Assessing Country Attractiveness of Indonesia and Recommended Entry Mode: Hospitality Industry. Australia: Monash University.

Porter, M.E. 1979. How Competitive Forces Shape Strategy. Harvard Business Review.

Porter, M. E. 2008. The Five Competitive Forces that Shape Strategy. Harvard Business Review.

Sofitel 2017, About Sofitel Bali terdapat pada http://www.sofitel.com/gb/hotel-9078-sofitelbali-nusa-dua-beach-resort-/index.shtml. Diakses pada tanggal 5 Maret 2017 pukul 07.10 WITA)

Starwood Preferred Guest 2017, Brunch St. Regis terdapat pada

http://upg.starwoodpromos.com/?u=B5AB98DE CB40D7D. Diakses pada tanggal 29 Maret 2017. 